\title{
What Future for Ultrasound in Medicine?
}

\author{
Welche Zukunft hat Ultraschall in der Medizin?
}

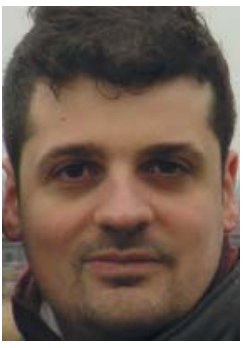

Francesco Tovoli

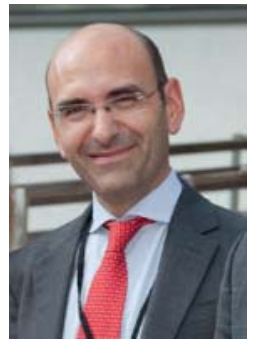

Vito Cantisani

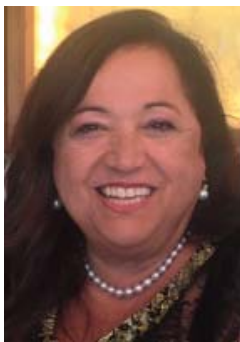

Cosima Schiavone

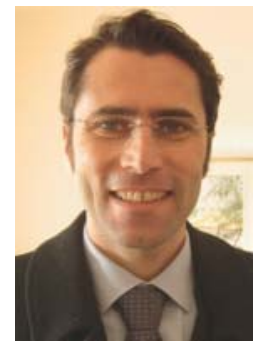

Fabio Piscaglia
Correspondence

Prof. Fabio Piscaglia

Dpt of Medical and Surgical Sciences DIMEC Unit of Internal

Medicine, via Albertoni 15, 40138 Bologna, Italy

fabio.piscaglia@unibo.it
Bibliography

DOI https://doi.org/10.1055/s-0043-125421

Published online: 2018

Ultraschall in Med 2018; 39: 7-10

(C) Georg Thieme Verlag KG, Stuttgart · New York

ISSN 0172-4614
What comes to mind when asked the question: "Welche Zukunft für Ultraschall in der Medizin" (What Future for Ultrasound in Medicine?)? I guess all of us would think about the editorial policies, publisher's choices and administrative issues of our beloved journal and might frown. However, at the beginning of the year 2018 , the future of the journal is fortunately very bright. It is quite successful and, therefore, the goal of this article is to review some new achievements and exciting future prospects of ultrasound techniques in the various medical fields, including those currently poised to be implemented in daily practice and those that are still only on the distant horizon. We hope readers will be able to discover future ultrasound applications that they are unaware of but may soon have a chance to use. We only regret that this overview will probably seem incomplete due to the limited publication space and the speed of change in these fields.

Cardiology is perhaps the most paradigmatic example of the manifold applications of ultrasound. With improvements in $3 \mathrm{D}$ and $4 \mathrm{D}$ interactive ultrasound techniques, the preoperative workup for transcatheter valve replacement/repair has gained a simple and noninvasive tool [1]. Even more remarkably, $3 \mathrm{D}$ printing companies are showing interest in printing models from ultrasound images, for instance from transesophageal exams, which could help with preoperative planning [2]. $3 \mathrm{D}$ echocardiography is expected to progressively become more integrated into the clinical guidelines and routine practice. Indeed, primary rather than secondary prevention is still the preferred approach in cardiovascular diseases.

With the current obesity epidemic, many developed countries around the world are seeking ways to improve weight loss. Ultrasound might play an unexpected role even in this setting.
Researchers from the United States recently described an innovative gene delivery therapy that produces an increase in fat and glucose oxidation and weight loss in diabetic rats, by genetically inducing a brown adipose tissue phenotype. In particular, a gene 'cocktail' was delivered into skeletal muscles of Zucker obese diabetic rats via tiny gas-filled microbubbles using ultrasound-targeted microbubble destruction (UTMD) [3]. This approach systemically infuses transgenes precoupled to gas-filled lipid microbubbles that are burst within the microvasculature of target tissues via an ultrasound signal, resulting in the release of DNA and transfection of neighboring cells within the tissue [3].

The therapeutic role of ultrasound has been established in the neurosciences, with focused ultrasound (FUS) having being approved for refractory essential tremor by the Food and Drug Administration (FDA) in 2016 [4]. It is currently under investigation as a possible treatment for disabling dyskinesia in Parkinson's disease, neuropathic pain, obsessive-compulsive disorder, and epilepsy [4]. Its ability to transiently open the blood-brain barrier in localized brain regions also offers a promising route for targeted drug delivery, potentially leading to novel therapeutic approaches in chemotherapy delivery for brain cancers [5] and in albumin-mediated plaque clearance in Alzheimer's disease [6]. FUS is not the only example of a medical use of ultrasound beyond mere imaging. Functional assessment might become a further application.

In particular, Ultrasound Optical Tomography (UOT) has recently shown promising results in the assessment of the blood oxygen saturation of deep sites, such as the front side of the myocardial tissue [7]. With sufficient improvement, this technique 
could provide a real-time noninvasive method to verify suspicion of heart infarction or angina.

The innovations regarding ultrasound techniques are not limited to the aforementioned fields. Ultrasound examination of the oral cavity structures, epiglottis, vocal cords, and subglottic space is becoming increasingly popular among anesthesiologists. The possible applications range from preoperative evaluation (vocal cord palsy or deviation/stenosis of the trachea) to postoperative management of the patient (positioning of endotracheal tube or laryngeal mask placement, navigating tool for emergency cricothyrotomy) [8]. Furthermore, endobronchial ultrasound is currently used for real-time navigated biopsy of pulmonary nodules [8] and is discussed in the current issue of the journal [9].

There are an increasing number of potential ultrasound applications even in a specialty such as dermatology. High-frequency $100 \mathrm{MHz}$ transducers have an axial resolution of $11 \mu \mathrm{m}$ and a lateral resolution of $30 \mu \mathrm{m}$ and allow visualization to a depth of $2 \mathrm{~mm}$. Clinical studies in psoriasis have shown very good correlation between ultrasound and histology in the evaluation of psoriatic plaques. Moreover, preliminary findings suggest that ultrasound is also able to capture modifications induced by local treatments, offering multiple new research perspectives [10].

In 2017 EFSUMB published an update of its liver elastography guidelines [11]. Ultrasound elastography has indeed been a revolution in many clinical fields and in hepatology in particular. However, it is still not the ultimate answer regarding all tissue characteristics, as it appears unable to properly distinguish fibrosis from interstitial pressure due to inflammatory edema. Experimental research suggests that refined analysis of ultrasound shear waves is able to produce information about viscoelasticity separate from information regarding fibrosis and stiffness [12]. This technical possibility could open the door to reliable and accurate noninvasive assessment of the many properties of tissues, including the liver.

One of the diseases with the greatest social impact in Western countries is Alzheimer's disease. Proper and early diagnosis is important from various points of view. Results of a study published in our journal in 2017 suggest that structural transcranial ultrasound is able to visualize and measure the medio-temporal lobe [13] and could possibly constitute a cheap and easy-to-use supplement to other techniques for the diagnosis of Alzheimer's disease by showing a small medio-temporal lobe. It may be especially useful as a screening tool in the large population of individuals with cognitive decline. Further studies are needed to validate this novel method.

Ultrasound has also been utilized for decades to support interventional procedures, with some of these applications being well established while others are relatively new and gaining popularity, such as vascular catheter guidance or endoscopic ultrasoundguided therapeutic interventions [14, 15].

In conclusion, the imaging potential of ultrasound in medicine is still tumultuously increasing, apparently at a much higher rate than other imaging methods, with a unique role also in therapeutic applications, leading to a definitive "cultural revolution" in the future of ultrasound in medicine. Hence, the future of Ultraschall in der Medizin is sure to be bright from all points of view.

\section{Welche Zukunft hat Ultraschall in der Medizin?}

Was kommt uns bei dieser Frage „Welche Zukunft hat Ultraschall in der Medizin?" in den Sinn? Ich denke, unsereins würde in Bezug auf unsere geliebte Zeitschrift zunächst an Redaktionspolitik, an Entscheidungen der Herausgeber und an administrative Belange denken und möglicherweise die Stirn runzeln. Allerdings ist das zu Beginn des Jahres 2018 zum Glück nicht der Fall. Die Zeitschrift ist erfolgreich und deshalb möchten wir an dieser Stelle eher einige neue Errungenschaften sowie vielversprechende Zukunftsperspektiven der sonografischen Methoden in den verschiedenen Fachgebieten der Medizin vorstellen. Diese schließen Techniken ein, die bereits jetzt in der täglichen Praxis Anwendung finden sowie diejenigen, die sich erst am Horizont abzeichnen. Wir hoffen, dass der Leser über seine aktuellen Kenntnisse hinaus auch neue Ultraschallanwendungen entdeckt, die ihm bald zur Verfügung stehen könnten. Wir bitten um Verständnis, dass diese Bestandsaufnahme aufgrund des hier limitierten Platzes und der rasanten Entwicklung auf diesem Gebiet voraussichtlich nicht ganz vollständig ist.

Die Kardiologie ist sicherlich das Musterbeispiel für den vielfältigen Einsatz der Sonografie. Mit den Verbesserungen der interaktiven 3D- und 4D-Ultraschalltechniken hat die präoperative Planung bei Transkatheter-Klappenersatz/Reparatur eine simple, nicht invasive Technologie dazu gewonnen [1]. Noch interessanter ist, dass die 3D-Druckertechnik es möglich macht, Modelle nach Ultraschallbildern beispielsweise aus transösophagealen Untersuchungen zu drucken, die bei der präoperativen Planung helfen könnten [2]. Es wird erwartet, dass die 3D-Echokardiografie zunehmend in die klinischen Leitlinien und die Routinepraxis integriert wird. Tatsächlich ist Primärprävention im Gegensatz zur Sekundärprävention immer noch der bevorzugte Ansatz bei Herz-Kreislauf-Erkrankungen.

Mit der aktuellen Fettleibigkeitsepidemie entsteht ein weltweiter Bedarf für eine erfolgreiche Reduzierung des Körpergewichts in vielen Industrienationen. Ultraschall könnte auch in diesem Bereich eine unerwartete Rolle spielen. US-amerikanische Forscher beschrieben kürzlich eine innovative Gentherapie, die bei diabetischen Ratten zu einem Anstieg der Fett- und Glukoseoxidation und zu Gewichtsverlust führte, indem sie einen braunen Fettgewebephänotyp genetisch induzierten. In diesem Fall wurde ein „Gen-Cocktail" über winzige gasgefüllte Mikropartikel durch ein Verfahren namens „Ultrasound-targeted microbubble destruction“ (UTMD) in die Skelettmuskeln von ZDF-Ratten („Zucker diabetic fatty rats“) geschleust [3]. Bei dieser Methode werden Transgene, die an gasgefüllte Lipid-Mikropartikel gekoppelt sind, systemisch in die Mikrovaskulatur des Zielgewebes infundiert und durch ein Ultraschallsignal zum Platzen gebracht, was zur Freisetzung von DNA und zur Transfektion benachbarter Zellen im Gewebe führt [3].

Die therapeutische (und lediglich diagnostische) Rolle des Ultraschalls ist in den Neurowissenschaften gut bekannt, wobei fokussierter Ultraschall (FUS) im Jahr 2016 von der „Food and Drug Administration“ (FDA) für den refraktären essenziellen Tremor zugelassen wurde [4]. Dieser wird derzeit als potenzielle 
Therapie von behindernden Dyskinesien bei Parkinson, von neuropathischen Schmerzen, Zwangsstörungen und Epilepsie untersucht [4]. Seine Fähigkeit, die Blut-Hirn-Schranke in lokalisierten Hirnregionen vorübergehend zu öffnen, zeigt einen vielversprechenden Weg für eine zielgerichtete Arzneimittelgabe auf und führt möglicherweise zu neuen therapeutischen Ansätzen bei der Chemotherapie von Gehirntumoren [5] und beim albuminvermittelten Abbau von Plaques bei Alzheimer [6]. FUS ist nicht das einzige Beispiel für den medizinischen Einsatz der Sonografie neben der reinen Bildgebung. Auch die funktionale Bewertung könnte ein weiterer Anwendungsbereich werden.

Insbesondere die ultraschalloptische Tomografie (UOT) zeigte kürzlich vielversprechende Ergebnisse bei der Beurteilung der Blutsauerstoffsättigung tiefliegender Stellen, wie der Vorderseite des Myokardgewebes [7]. Mit ausreichenden Verbesserungen könnte diese Technik eine nicht invasive Echtzeitmethode darstellen, um die Verdachtsdiagnose Herzinfarkt oder Angina zu verifizieren.

Die durch Ultraschalltechniken erzielten Innovationen beschränken sich nicht ausschließlich auf die zuvor genannten Gebiete. Die Sonografie der Mundhöhlenstrukturen, der Epiglottis, der Stimmbänder und des subglottischen Raums wird unter den Anästhesiologen immer beliebter. Die möglichen Anwendungen reichen von der präoperativen Beurteilung (Stimmbandlähmung oder Deviation/Stenose der Luftröhre) bis zum postoperativen Management des Patienten (Positionierung des Endotrachealtubus oder Einlegen der Larynxmaske, Navigationssystem für die NotfallKoniotomie) [8]. Darüber hinaus wird der endobronchiale Ultraschall derzeit in der Echtzeitnavigation bei Biopsien von Lungenknoten verwendet [8]. Diese Methode wird in der aktuellen Ausgabe der Zeitschrift [9] dargestellt.

Auch ein Fachbereich wie die Dermatologie verzeichnet eine stetige Zunahme der sonografischen Anwendungsmöglichkeiten. Hochfrequenzschallköpfe von $100 \mathrm{MHz}$ haben eine axiale Auflösung von $11 \mu \mathrm{m}$, eine laterale Auflösung von $30 \mu \mathrm{m}$ und ermöglichen eine Visualisierung bis zu einer Tiefe von $2 \mathrm{~mm}$. Klinische Studien zur Psoriasis zeigen sehr gute Korrelationen zwischen Ultraschall und Histologie bei der Beurteilung psoriatischer Plaques. Vorläufige Ergebnisse deuten ebenfalls darauf hin, dass Ultraschall in der Lage ist, die durch lokale Behandlungen induzierten Veränderungen zu erfassen, was eine Vielzahl neuer Forschungsperspektiven bietet [10].

Im Jahr 2017 hat die EFSUMB eine Aktualisierung ihrer Leberelastografie-Leitlinien veröffentlicht [11]. Die Ultraschallelastografie war tatsächlich in vielen klinischen Fachbereichen und insbesondere in der Hepatologie eine Revolution, aber sie stellt noch nicht die ultimative Lösung dar, was die Information bezüglich der Eigenschaften aller Gewebe betrifft, da sie offenbar nicht exakt in der Lage ist, zwischen einer Fibrose und dem durch ein entzündlichen Ödem verursachten interstitiellen Druck zu differenzieren. Experimentelle Untersuchungen legen nahe, dass durch eine verfeinerte Analyse von Ultraschallscherwellen Informationen über die Viskoelastizität, unabhängig von Fibrose und Steifigheit, generiert werden [12]. Diese technische Möglichkeit könnte der Beginn einer zuverlässigen und treffsicheren nicht invasiven Bewertung der vielen Eigenschaften von Geweben, einschließlich der Leber, eröffnen.
In den westlichen Ländern ist die Alzheimer-Demenz einer der Krankheiten mit den größten sozialen Auswirkungen. Eine genaue und frühzeitige Diagnosestellung ist aus verschiedenen Blickwinkeln entscheidend. Ergebnisse einer Studie, die 2017 in unserer Zeitschrift veröffentlicht wurde, legen nahe, dass der Einsatz der strukturellen transkraniellen Sonografie eine Visualisierung und Messung der mediotemporalen Lappen ermöglicht [13]. Der Nachweis eines kleinen Lappens ist neben anderen Techniken möglicherweise ein billiges und einfach anzuwendendes Verfahren, um die Diagnose bei Alzheimer-Demenz zu stellen. Ultraschall könnte insbesondere als Screening-Methode bei der großen Zahl von Menschen mit kognitivem Verfall besonders nützlich sein. Weitere Studien sind notwendig, um diese neue Methode zu validieren.

Ultraschall wird seit Jahrzehnten auch zur Unterstützung von interventionellen Anwendungen eingesetzt, von denen einige gut etabliert sind, während andere relativ neu sind und an Popularität gewinnen, wie z. B. die Führung von vaskulären Kathetern oder ultraschallgesteuerte therapeutische Interventionen in der Endoskopie [14, 15].

Zusammenfassend ist festzuhalten, dass die Möglichkeiten der Bildgebung von Ultraschall in der Medizin noch immer tumultartig mit wesentlich größerer Geschwindigkeit als bei anderen bildgebenden Verfahren ansteigt; mit einer einzigartigen Rolle auch bei den therapeutischen Anwendungen. Dies führt definitiv zu einer Art „Kulturrevolution“ was die Zukunft von Ultraschall in der Medizin betrifft. Daher wird die Zukunft unserer „Ultraschall in der Medizin“ - aus allen Blickwinkeln betrachtet - sicher vielversprechend sein.

\section{References}

[1] Kwon SH, Gopal AS. 3D and 4D Ultrasound: Current Progress and Future Perspectives. Curr Cardiovasc Imaging Rep 2017; 10: 43 doi:10.1007| s12410-017-9440-2

[2] Mashari A. Making three-dimensional echocardiography more tangible: a workflow for three-dimensional printing with echocardiographic data. Echo Res Pract 2016; 3: R57 - R64

[3] Bastarrachea RA, Chen J, Kent JW Jr et al. Engineering brown fat into skeletal muscle using ultrasound-targeted microbubble destruction gene delivery in obese Zucker rats: Proof of concept design. IUBMB Life 2017; 69: $745-755$

[4] Krishna V, Sammartino F, Rezai A. A Review of the Current Therapies, Challenges, and Future Directions of Transcranial Focused Ultrasound Technology: Advances in Diagnosis and Treatment. JAMA Neurol 2017. doi:10.1001/jamaneurol.2017.3129

[5] Choi J], Feshitan JA, Baseri B et al. Microbubble-size dependence of focused ultrasound-induced blood-brain barrier opening in mice in vivo. IEEE Trans Biomed Eng 2010; 57: 145-154

[6] Leinenga G, Götz J. Scanning ultrasound removes amyloid- $\beta$ and restores memory in an Alzheimer's disease mouse model. Sci Transl Med 2015; 7: 278ra3 doi:10.1126/scitranslmed.aaa2512

[7] Walther A, Rippe L, Wang LV et al. Analysis of the potential for non-invasive imaging of oxygenation at heart depth, using ultrasound optical tomography (UOT) or photo-acoustic tomography (PAT). Biomed Opt Express. 2017 8: $4523-4536$

[8] Votruba J, Zemanová P, Lambert L et al. The Role of Airway and Endobronchial Ultrasound in Perioperative Medicine. Biomed Res Int 2015. doi:10.1155/2015/754626 
[9] Darwiche K, Özkan F, Wolters C et al. Endobronchial Ultrasound (EBUS) Update 2017. Ultraschall Med 2018; 39: 14-38

[10] Crisan M, Badea R, Crisan D et al. Ultrasonography as a New, Non-Invasive Imagistic Technique Used for the Diagnosis and Monitoring of Psoriasis. In "An Interdisciplinary Approach to Psoriasis". (InTech Open, 2017)

[11] Dietrich CF, Bamber J, Berzigotti A et al. EFSUMB Guidelines and Recommendations on the Clinical Use of Liver Ultrasound Elastography, Update 2017. Ultraschall Med 2017; 38: 377-394
[12] van Sloun RJG, Wildeboer RR, Wijkstra $\mathrm{H}$ et al. Viscoelasticity Mapping by Identification of Local Shear Wave Dynamics. IEEE Trans Ultrason Ferroelectr Freq Control 2017; 64: 1666-1673

[13] Yilmaz R, Pilotto A, Roeben B et al. Structural Ultrasound of the Medial Temporal Lobe in Alzheimer's Disease. Ultraschall Med 2017; 38: 294 - 300

[14] Jenssen C, Brkljacic B, Hocke M et al. EFSUMB Guidelines on Interventional Ultrasound (INVUS), Part VI - Ultrasound-Guided Vascular Interventions. Ultraschall Med 2016; 37: 473-476

[15] Fusaroli P, Jenssen C, Hocke M et al. EFSUMB Guidelines on Interventional Ultrasound (INVUS), Part V - EUS-Guided Therapeutic Interventions. Ultraschall Med 2016; 37: 412-420 